\title{
Biofortification of wheat grain with copper through soil fertilization ${ }^{1}$
}

\section{Biofortyfikacja ziarna pszenicy miedzią poprzez nawożenie doglebowe}

\author{
*Dr hab. inż. Jolanta Korzeniowska, prof. nadzw., mgr inż. Katarzyna Kantek, \\ Department of Weed Science and Soil Tillage Systems in Wroclaw, Institute \\ of Soil Science and Plant Cultivation - State Research Institute in Pulawy, \\ Orzechowa 61 St., 50-540 Wroclaw, Poland, phone: +48 713638707 \\ e-mail: j.korzeniowska@iung.wroclaw.pl, k.kantek@iung.wroclaw.pl
}

Keywords: wheat grain, copper concentration, soil application, pot experiment

Słowa kluczowe: ziarno pszenicy, zawartość miedzi, nawożenie doglebowe, doświadczenie wazonowe

\begin{abstract}
In recent years, in the literature, there have been frequent reports of insufficient amounts of copper in the diet of various groups of the inhabitants of our country. This is disturbing as the adequate input of copper is significant from the point of view of prevention of cardiovascular diseases. At the same time, grain of wheat cultivated in Poland is characterized by low content of this element. Considering that the main source of $\mathrm{Cu}$ is bread and cereal preparations, the important issue is to increase the content of $\mathrm{Cu}$ in the grain of wheat. If the deficiency in the diet is accompanied by the deficiencies in the soil, biofortification through fertilization is a favourable solution. Pot experiments have shown the possibility to significantly increase $\mathrm{Cu}$ content in the grain of wheat as a result of soil fertilization with copper. It was also found that a small difference between the deficiency and surplus of $\mathrm{Cu}$ in the grain may lead to some copper excess content, especially on the soils with low organic matter content. For this reason, biofortification of wheat with copper requires a precise determination of soil fertilization doses under the conditions of field experiments.
\end{abstract}

\section{Streszczenie}

W ostatnich latach w literaturze pojawiaja się częste doniesienia o niewystarczającej ilości miedzi w diecie różnych grup mieszkańców naszego kraju. Jest to niepokojące, ponieważ odpowiednia podaż miedzi jest istotna z punktu widzenia profilaktyki chorób sercowo-naczyniowych. Jednocześnie ziarno pszenicy uprawianej w Polsce charakteryzuje się niską zawartością tego pierwiastka. Biorąc pod uwagę, że głównym źródłem Cu jest pieczywo i przetwory zbożowe, istotnym zagadnieniem jest zwiększenie zawartości Cu w ziarnie pszenicy. W sytuacji, gdy niedoborom w diecie towarzyszą niedobory w glebie, korzystnym rozwiązaniem jest biofortyfikacja poprzez nawożenie. W przeprowadzonych badaniach w warunkach doświadczenia wazonowego wykazano możliwość znaczącego zwiększenia zawartości Cu w ziarnie pszenicy na skutek nawożenia doglebowego miedzią. Stwierdzono również, że mała różnica pomiędzy niedoborem a nadmiarem $\mathrm{Cu}$ w ziarnie może prowadzić do wystapienia jej nadmiernych zawartości, szczególnie na glebach o niskiej zawartości materii organicznej. Z tego powodu biofortyfikacja ziarna pszenicy miedzią wymaga precyzyjnego ustalenia doglebowych dawek nawozowych w warunkach doświadczeń polowych.

(C) IOŚ-PIB

\section{INTRODUCTION}

More than $40 \%$ of people in the world suffer from micronutrient deficit, which is the reason for various health problems [Murphy et al. 2008, Progress report 2000]. While in the world, there are mostly deficiencies of iron and zinc [White and Zasoski 1999], in Poland, the additional problem is an insufficient amount of copper in food and animal feed. It is connected with a considerable amount of soils with low content of this element in our country [Bombik et al. 2004]. According to the latest studies of Polish agrochemical laboratories, up to $34 \%$ of the arable soils in Poland have deficiencies of copper available to plants [Lipiński 2013].

An adequate supply of copper from the diet is important from the point of view of prevention of cardiovascular disease (CVD) [Terlikowska et al. 2013]. Copper is a part of the antioxidant enzymes (e.g. superoxide dismutase), and its deficiency in the diet can lead to disorders of the antioxidant system in the body. This is connected with the occurrence of oxidative stress, which can lead to CVDs [Grygiel-Górniak 2010, Klevay 2000, Suliburska 2010, UriuAdams and Keen 2005]. It is estimated that CVD causes nearly

$50 \%$ of all deaths in Europe. According to the European Cardiovascular Disease Statistics, coronary heart disease is the cause of $21 \%$ of deaths, stroke $-12.5 \%$, while other CVDs cause $13.5 \%$ of deaths among the residents of Europe [Nichols et al. 2012]

An insufficient amount of copper in the diet can be dangerous not only for people but also for farm animals. Cu deficiencies lead to anaemia, reduce growth and fertility, cause bone breakability and nervous system disorders [Kluczek 2006, Sikora 2007, Zatta and Frank, 2007].

In recent years, many authors have reported insufficient amount of copper in the diet of the inhabitants of our country. Bronkowska and Karcz [2007] recorded a very low consumption of copper (36.5\% of normal) in the test group of 100 women with professional low physical activity. A similar low consumption $(40.4 \%$ of normal) was observed in a group of 100 women in perimenopause [Bronkowska et al. 2009]. Staniek et al. [2006] have shown, on the basis of the menu of the orphanage in Trzemeszno and the home of social assistance in Skubarczewo, that the daily food diets of 
the elderly and children provide too little of $\mathrm{Cu}$. According to Jaworska and Bazylak [2007], copper requirements of female pharmacy students in Bydgoszcz, estimated for 73 persons, were satisfied only in $44-49 \%$. The analysis of the Cu content in hair during perimenopause has shown the possibility of copper deficiencies in a relatively large part of the population of older women [Wlaźlak et al. 2007]. Bolesławska et al. [2009] have shown a too low level of copper intake in the randomly selected group of 723 men and women. On the basis of studies among 78 students of Warsaw schools, the average content of $\mathrm{Cu}$ in the diet of young people was only $50-60 \%$ of the recommended daily supply [Dybkowska et al. 2011]. According to Wielgos et al. [2012], the intake of copper in daily diets of 157 students from randomly selected schools from Cracow and Skawina generally did not meet the requirements for this element.

The main source of copper in the diet of Poles is bread and cereals [Dybkowska et al. 2011, Seidler et al. 2013], i.e. grain cereals. Thus, a low Cu content in the grain of Polish wheat is a concerning issue. According to previous studies on the national scale, it amounted to an average from 2.6 to $3.4 \mathrm{mg} \cdot \mathrm{kg}^{-1}$ for the country [Gembarzewski et al. 1995, Report 2002, Wojciechowska et al. 1995, Wróbel 2000]. Currently, there are no studies covering the whole country, but frequent reports of shortages of this element in the diet suggest that it is still insufficient.

It should be noted that the content at the level of $2.6-3.4 \mathrm{mg} \cdot \mathrm{kg}^{-1}$ is also insufficient from the point of view of nutritional requirements of farm animals. According to Polish authors, the standard copper content of the animal feed is 10 [Falkowski et al. 2000, Kruczyńska 1985], and according to American National Research, it ranges from 3 to $16 \mathrm{mg} \cdot \mathrm{kg}^{-1} \mathrm{Cu}$ depending on the species and age group [USA NRC 1989, 1994, 1998, 2000, 2001]

In the case of deficiencies of micronutrients in the diet, biofortification of cereal grains seems to be the most cost-effective solution [Bouis et al. 2011]. Different strategies of biofortification, such as application of fertilizers, traditional breeding and genetic engineering, are widely discussed in the world literature [Bashir et al. 2013, Cakmak 2008, Velu et al. 2014]. When the deficiencies in the diet are accompanied by the deficiencies in the soil, biofortification through fertilization seems to be the most advantageous solution. The aim of this study was to examine the possibility of increasing copper content in winter wheat grain through soil fertilization with this element.

\section{MATERIALS AND METHODS}

In 2012-2013, at the Experimental Station of IUNG-PIB in JelczLaskowice near Wrockaw, a 2-year pot experiment with soil fertilization of spring wheat with copper was conducted. The experiment was established in a completely randomized design in eight replicates, the four of which were collected in the beginning stage of shooting and the other four in the stage of full grain maturity. The experiment included two types of soils - S1 and S2, which were previously sieved through a sieve with a diameter of $1 \mathrm{~cm}$ and limed at a dose of $12 \mathrm{~g}$ of $\mathrm{CaCO}_{3}$ per pot. Soil S2 was obtained by adding organic matter in the form of de-acidified peat to soil S1 in the ratio of $1: 8$. The description of the soils used in the experiment is presented in Table 1 .
The experiment was performed in Wagner pots filled with $9 \mathrm{~kg}$ of soil. Copper was introduced into the soil in the first year of the experiment for a month before sowing of wheat in the following doses: $0,5,10,30$ and $60 \mathrm{mg}$ Cu per pot in the form of $\mathrm{Cu}_{2} \mathrm{SO}_{4} \cdot 5 \mathrm{H}_{2} \mathrm{O}$. In addition, a micronutrient medium with the composition of $1.6 \mathrm{mg}$ Mo, $4.1 \mathrm{mg} \mathrm{B}, 8.4 \mathrm{mg} \mathrm{Zn,} 23.3 \mathrm{mg} \mathrm{Mn}$ and $62.5 \mathrm{mg}$ Na per pot was applied once in all the treatments before the sowing.

The test plant was wheat of Jasna variety. Initially, 23 grains of wheat were sown per pot, and after reaching the three-leaf stage, 17 plants per pot were left. Every year, the plants were fertilized with nitrogen before sowing and during the beginning of shooting, in a total dose of $1.8 \mathrm{~g} \mathrm{~N}$ in the form of $\mathrm{NH}_{4} \mathrm{NO}_{3}$ per pot. Soil moisture was maintained at $60 \%$ of field water capacity.

In both years of the study (2012 and 2013), samples of whole above ground parts in the beginning stage of shooting, cut $5 \mathrm{~cm}$ above the ground, and samples of grains in the stage of full maturity were collected for the determinations of copper in plant material . Soil samples were collected three times: in spring 2012 after liming and mixing the soil with peat and before $\mathrm{Cu}$ fertilization - for performing the characteristics of the experimental soils, and after harvest in 2012 and 2013 - for the determinations of available copper The copper content in the plant samples was determined by FAAS method. The analyses were performed after prior ashing of ground, air-dry samples in a muffle furnace and dissolving them in hydrochloric acid. Copper in the soil was determined by AAS method after prior extraction in $1 \mathrm{M} \mathrm{HCl}$. Furthermore, the soil texture was determined by sieve-aerometric method, $\mathrm{pH}$ in $1 \mathrm{M} \mathrm{KCl}$ and the content of organic carbon by oxidation method.

Available phosphorus and potassium were determined by Egner-Riehm's method in $0.04 \mathrm{M} \mathrm{Ca}\left(\mathrm{CH}_{3} \mathrm{CHOHCOO}\right)_{2} \cdot 5 \mathrm{H}_{2} \mathrm{O}$ and available forms of magnesium were determined according to Schachtschabel' method in $0.0125 \mathrm{M} \mathrm{CaCl}_{2}$.

ANOVA calculation was performed with the use of AWAR program [Filipiak and Wilkos 1995]. The comparisons of differences between the means for treatments were made using the multiple Tukey's test. All the presented results are the average of 2 years of the research.

\section{RESULTS AND DISCUSSION}

In the experiment, wheat was grown on two soils: $\mathrm{S} 1$ and $\mathrm{S} 2$ which differed mainly in terms of organic matter content and $\mathrm{pH}$ level (Table 1). Both of these features of the soil affect the availability of $\mathrm{Cu}$ to plants and an increase of them limits the bioavailability of this element. This relationship was also observed in our study. Wheat growing in the soil S2 without $\mathrm{Cu}$ (S2Cu0 treatment) contained by about $10 \%$ less copper in the shoots and by $40 \%$ in the grain compared with the wheat of $\mathrm{S} 1 \mathrm{Cu} 0$ (Figs 1 and 2). In the beginning stage of shooting, the wheat from the treatments without $\mathrm{Cu}$ growing on $\mathrm{S} 1$ contained $6.2 \mathrm{mg} \cdot \mathrm{kg}^{-1}$, and on $\mathrm{S} 2$ $5.7 \mathrm{mg} \cdot \mathrm{kg}^{-1}$ of copper (Fig. 1). It is difficult to assess whether these values were sufficient for its growth and development since different authors give different critical limits for this stage. According to Bergmann [1992], the deficiency is below $7 \mathrm{mg} \cdot \mathrm{kg}^{-1}$, while according to Shnug and Haneklaus [2008], it is below $4 \mathrm{mg} \cdot \mathrm{kg}^{-1}$. Cu content below $3 \mathrm{mg} \cdot \mathrm{kg}^{-1}$ in the grain is insufficient for correct yielding of wheat and too low to meet the needs of farm animals

Table 1. Characteristics of experiment soils

\begin{tabular}{|c|c|c|c|c|c|c|c|c|c|c|c|}
\hline Soil & Soil type & Fraction $<0.002 \mathrm{~mm}(\%)$ & $\mathrm{pH}$ & $\mathrm{C}$ org (\%) & $\mathrm{P}$ & $\mathrm{K}$ & $\mathrm{Mg}$ & $\mathrm{Ca}$ & $\mathrm{Cu}$ \\
\hline S1 & Loamy sand & 1.4 & 6.2 & 0.7 & 165 & 116 & 100 & 1564 & 2.2 \\
\hline S2 & Loamy sand & 1.4 & 6.6 & 2.3 & 253 & 99 & 120 & 2187 & 2.3 \\
\hline
\end{tabular}




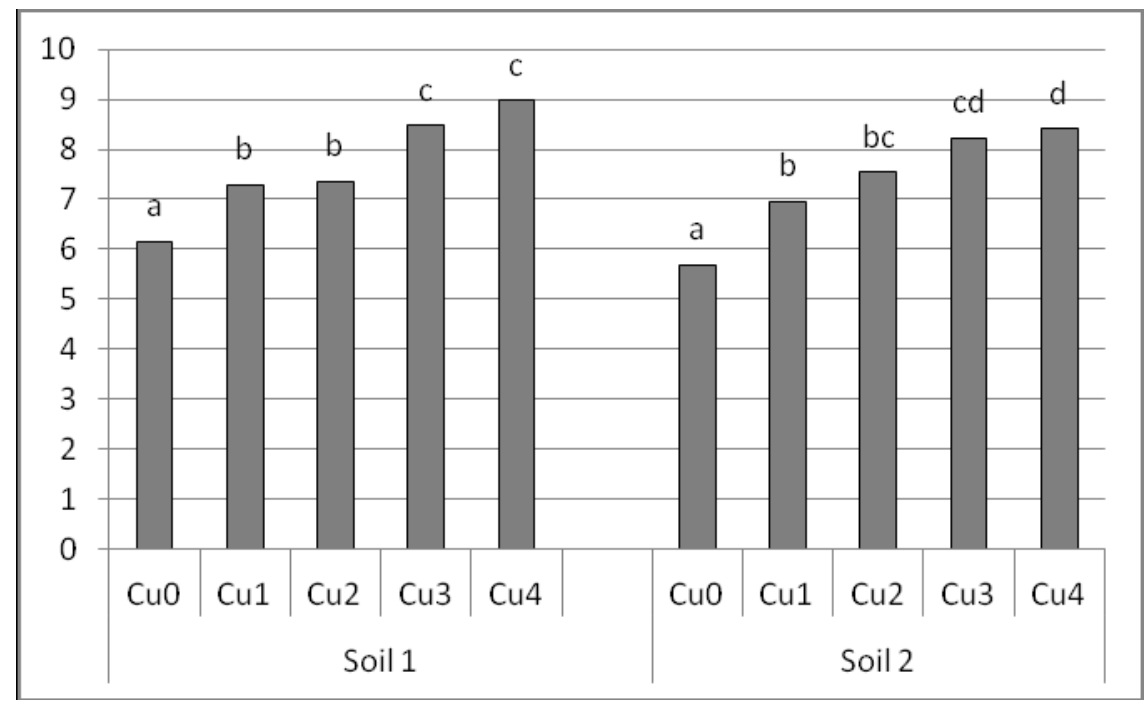

Fig. 1. Copper concentration in shoots $\left(\mathrm{mg} \cdot \mathrm{kg}^{-1}\right)$

[Kirchmann et al. 2009]. Copper deficiency is a serious problem for ruminants in many parts of the world [McDowell 2003].

At the same time, the content above $6 \mathrm{mg} \cdot \mathrm{kg}^{-1}$ is dangerous from the point of view of possible surplus of copper in the diet [KabataPendias and Mukherjee 2007, Raport 2002]. The optimal range of $3-6 \mathrm{mg} \cdot \mathrm{kg}^{-1} \mathrm{Cu}$ in the grain is rather narrow. There is some risk of excessive increase of $\mathrm{Cu}$ amount in the grain under the influence of high doses of fertilizer.

In our experiment, the copper content in the grain of control treatment was on the verge of deficiency in the soil S1 $\left(3.0 \mathrm{mg} \cdot \mathrm{kg}^{-1}\right)$ or well below this limit in soil S2 $\left(1.9 \mathrm{mg} \cdot \mathrm{kg}^{-1}\right)$ (Fig. 2). It should be noted that the content in S2 was significantly lower than that reported by other Polish authors. In general, the Cu content in wheat grain grown on Polish territory was at the level of 2.6-3.4 [Gembarzewski et al. 1995, Raport 2002, Wojciechowska et al. 1995, Wróbel 2000]. However, the majority of Polish soils are characterized by both a significantly lower content of $\mathrm{C}$ org, as well as by lower levels of $\mathrm{pH}$ than the soil $\mathrm{S} 2$, which may be the reason for the greater availability of copper and its higher contents in wheat plants in the country. This indicates that the wheat grown on limed soils with above average organic matter content may require fertilization with copper.
Soil fertilization with increasing doses of copper resulted in an increase in its content in the shoots and grains of wheat. The largest increase in its content occurred at the highest dose of Cu4 and amounted to $45 \%$ for S1 and $48 \%$ for S2 in the shoots, and $88 \%$ for S1 and $125 \%$ for S2 in the grain (Figs 1 and 2). For soil S1, all the applied doses of $\mathrm{Cu}$ raised its content in the grain above $3 \mathrm{mg} \cdot \mathrm{kg}^{-1}$, which is the limit of deficiency. It should be noted that the highest dose $\mathrm{Cu} 4$ caused a high increase in the content, close to $6 \mathrm{mg} \cdot \mathrm{kg}^{-1}$. This situation did not occur in the soil S2. In contrast to soil $\mathrm{S} 1$, the doses of $\mathrm{Cu} 1-\mathrm{Cu} 2$ did not counteract the deficiencies. Only the doses of $\mathrm{Cu} 3$ and $\mathrm{Cu} 4$ provided sufficient copper content in the grain, while at the same time not approaching to the excess limit.

In soil S2, an increase in the copper amount in the grain under the influence of fertilization corresponded with increasing amounts of copper in the soil (Fig. 3). Similarly like in the grain, only the doses of $\mathrm{Cu} 3$ and $\mathrm{Cu} 4$ significantly raised the content of available $\mathrm{Cu}$ in the soil to the level 8.6-9.1 $\mathrm{mg} \cdot \mathrm{kg}^{-1}$ (Fig. 3). In soil S1, Cu content in the soil increased steadily in the range of $2.2-8.2 \mathrm{mg} \cdot \mathrm{kg}^{-1}$.

The obtained results indicate the possibility of biofortification of wheat grain with copper by soil fertilization. Foliar fertilization often does not allow for biofortification of grains with microelements.

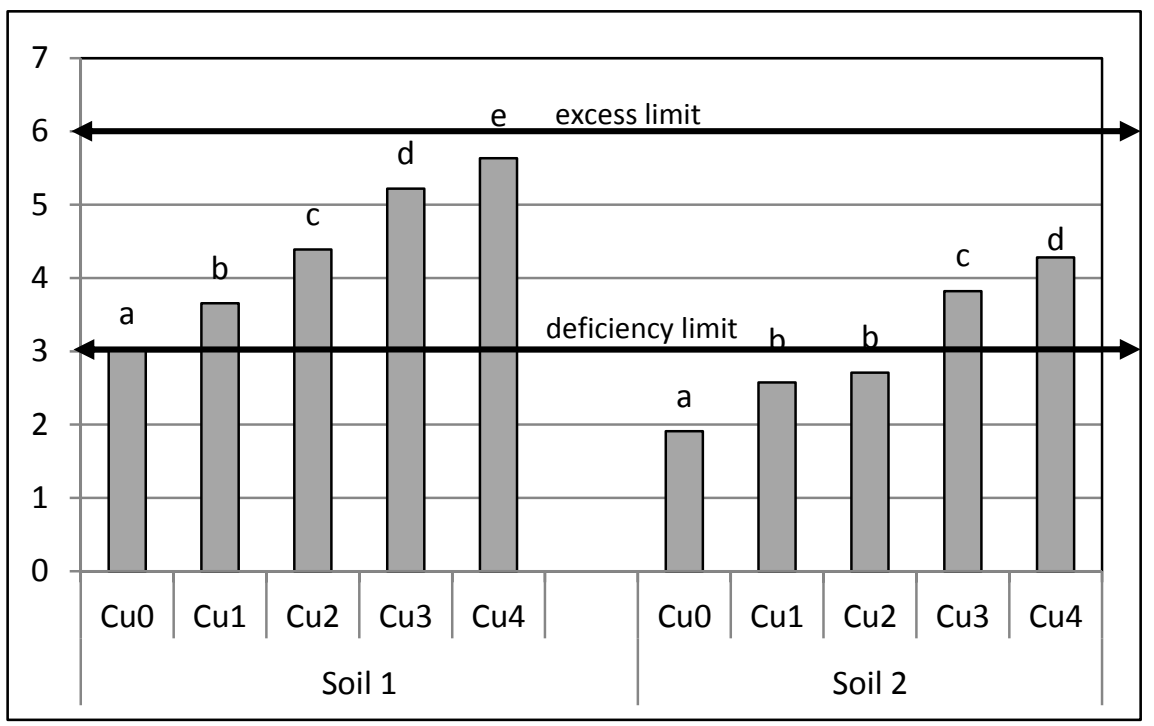

Fig. 2. Copper concentration in wheat grain $\left(\mathrm{mg} \cdot \mathrm{kg}^{-1}\right)$ 
Earlier studies of these authors showed that doses in foliar fertilization are too small to cause $\mathrm{Cu}$ increase in the grain [Korzeniowska and Stanisławska 2011]. In the soils with copper deficiencies, fertilization causes an increase in yields, which in the case of insufficient doses leads to the dilution. It prevents the increase in copper content in the grain.

In the world literature, there is a lack of research on biofortification of grain with copper. This is most likely the result of a rare deficiency of this element in the diet of people from other regions of the world. Many authors investigate the problem of grain biofortification with zinc [Hussain et al. 2012, McGrath et al. 2012, Phattarakul et al. 2012], iron [Aciksoz et al. 2011] and selenium [Lyons et al. 2005].

\section{SUMMARY}

Soil fertilization with copper can significantly increase the content of that element in the grain of wheat in the case of its deficiencies. The soil with higher $\mathrm{pH}$ and organic matter content requires the use of higher doses of copper than poorer and more acidic soils. Due to the small difference between deficiency and excess of copper in the grain the possibility of $\mathrm{Cu}$ excess must be taken under consideration in the case of its inappropriate doses. In particular, it concerns the soils with low organic carbon content. Biofortification of wheat grain with copper through soil fertilization can be effective; however, it requires a precise determination of the dose of fertilizer depending on the type of soil under the conditions of field experiments.

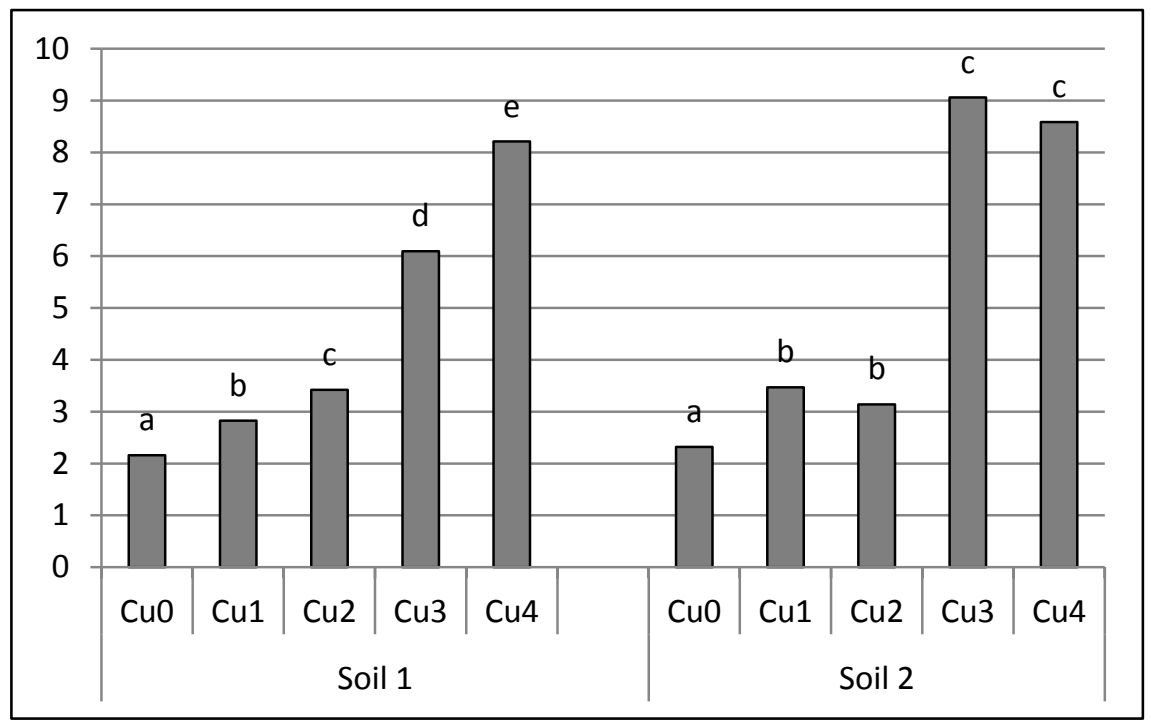

Fig. 3. Available copper concentration in soil after harvest $\left(\mathrm{mg} \cdot \mathrm{kg}^{-1}\right)$

\section{REFERENCES AND LEGAL ACTS}

ACIKSOZ S. B., YAZICI A., OZTURK L., CAKMAK I. 2011. Biofortification of wheat with iron through soil and foliar application of nitrogen and iron fertilizers. Plant and Soil 349 : 215-225.

BASHIR K., TAKAHASI R., NAKANISHI H., NISHIZAWA N.K. 2013. The road to micronutrient biofortification of rice: progress and prospects. Frontiers in Plant Science 4,15:1-7.

BREGMAN W. 1992. Nutritional disorders of plants - development, visual and analytical diagnosis. Gustav Fischer Verlag Jena, Stuttgart. New York. 343-361.

BOLESŁAWSKA I., PRZYSŁAWSKI J., SCHHLEGEL-ZAWADZKA M., GRZYMISŁAWSKI M. 2009. Zawartość składników mineralnych w całodziennych racjach pokarmowych kobiet i mężczyzn stosujących dietę tradycyjną i „optymalna” - analiza porównawcza. Żywność. Nauka. Technologia. Jakość. 4 (65): 303-311.

BOMBIK T., BOMBIK E., SABA L., TRAWIŃSKA B. 2004. Zależność między występowaniem miedzi w glebie, paszach i organizmie krów. Zeszyty Naukowe Akademii Rolniczej we Wrocławiu 501: 45-50.

BOUIS H. E., McCLAFFERTY B., MEENAKSHI J. V., PFEIFFER W. H. 2011. Biofortification: a new tool to reduce micronutrient malnutrition. Food and Nutrition Bulletin 32 : 31-40

BRONKOWSKA M., BIERNAT J., SADOWSKA B. 2009. Podaż wybranych składników mineralnych $w$ racjach pokarmowych kobiet w okresie okołomenopauzalnym. Bromatologia i Chemia Toksykologiczna 46, 1 : 24-29.
BRONKOWSKA M., KARCZI. 2007. Ocena zawartości wybranych mikro- i makroelementów w całodziennych racjach pokarmowych kobiet o niskiej aktywności fizycznej. Roczniki PZH. 58, $4: 609-615$.

CAKMAK I. 2008. Enrichment of cereal grains with zinc: Agronomic or genetic biofortification. Plant and Soil $302: 1-17$.

DYBKOWSKA E., ŚWIDERSKI F., WASZKIEWICZ-ROBAK B. 2011. The content of trace elements in the diet of adolescents in Warsaw. Roczniki Państwowego Zakładu Higieny 62, 2 : 169172.

FALKOWSKI M., KUKUŁA I., KOZŁOWSKI S. 2000. Właściwości chemiczne roślin łąkowych. Wyd. AR Poznań. 1-132.

FILIPIAK K., WILKOS S. 1995: Obliczenia statystyczne. Opis systemu AWAR. IUNG Puławy 324: 35-36.

GEMBARZEWSKI H., OBOJSKI J., STRACCZYŃSKI S., SIENKIEWICZ U. 1995. Zawartość makro i mikroelementów w glebach oraz roślinach ziemniaka i pszenicy ozimej z pól o wysokiej produkcyjności. IUNG Puławy $80:$ 1-38.

GRYGIL-GÓRNIAK B. 2010. Stres oksydacyjny jako czynnik ryzyka kardio- diabetologicznego fakty i mity. Bromatologia i Chemia Toksykologiczna 43, 2 : 109-117.

HUSSAIN S., MAQSOOD M. A., RENGEL Z., AZIZ T. 2012. Biofortification and estimated human bioavailability of zinc in wheat grains as influenced by methods of zinc application. Plant and Soil 361 : 279-290. 
JAWOROWSKAA., BAZYLAK G. 2007. Residential factors affecting nutrient intake and nutritional status of female pharmacy students in Bydgoszcz. Roczniki Państwowego Zakładu Higieny $58,1: 245-251$.

KABATA-PENDIAS A., MUKHERJEE A. B. 2007. Trace elements from soil to human. Springer-Verlag. Berlin. New York. 1-550.

KLEVAY L. M. 2000. Cardiovascular disease from copper deficiency—A history. The Journal of Nutrition $130:$ 489-492.

KLUCZEK S. 2006. Współzależność między masa ciała a poziomem miedzi i ceruloplazminy w surowicy krwi świń mieszańców w okresie tuczu. Prace Wydziału Nauk Przyrodniczych. Prace Komisji Nauk Rolniczych i Biologicznych. Seria B, 59: 27-32.

KIRCHMANN H., MATTSSON L., ERIKSSON J. 2009. Trace element concentration in wheat grain: results from the Swedish long-term soil fertility experiments and national monitoring program. Environmental Geochemistry and Health, 31: 561-571

KORZENIOWSKA J., STANISŁAWSKA-GLUBIAK E. 2011. The effect of foliar application of copper on content of this element in winter wheat grain. Polish Journal of Agronomy 4: 3-6.

KRUCZYŃSKA H., 1985. Liczby graniczne zawartości mikroelementów w roślinach dla oceny ich wartości paszowej. Nowe Rolnictwo 9: 45-47.

LIPIŃSKI W. 2013. Zasobność gleb Polski w mikroelementy. Studia i raporty IUNG-PIB 34, 8: 121-131.

LYNOS G. H., JUDSON G. J., ORTIZ-MONASTERIO I., GENC Y., STANGOULIS J. C. R., GRAHAM R. D. 2005. Selenium in Australia: Selenium status and biofortification of wheat for better health. Journal of Trace Elements in Medicine and Biology 19: 75-82.

McDOWELLL. R. 2003. Minerals in animal and human nutrition.2nd ed. Elsevier Science. 1-644

McGRATH S. P., CAHMNERS B. J., TAYLOR M. J., CARLTONSMITH C., H. 2012. Biofortification of zinc in wheat grain by the application of sewage sludge. Plant and Soil 361: 97-108.

Murphy K.M., Reeves P.G., Jones S.S. 2008. Relationship between yield and mineral nutrient concentrations in historical and modern spring wheat cultivars. Euphytica 163: 381-390.

NICHOLS M., TOWNSEND N., LUENGO-FERNANDEZ R., LEAL J., GRAY A., SCARBOROUGH P., RAYNER M. 2012. European Cardiovascular Disease Statistics 2012. European Heart Network, Brussels, European Society of Cardiology, Sophia Antipolis.

PHATTARAKUL N., RERKASEM B., LI L. J., WU L. J., ZOU C. Q., RAM H., SOHU V. S., KANG B. S., SUREK H., KALAYCI M., YAZICI A., ZHANG F. S., CAKMAK I. 2012. Biofortification of rice grain with zinc through zinc fertilization in different countries. Plant and Soil 361:131-141.

PROGRESS REPORT. 2000. Nutrition for Health and Development. A global agenda for combating malnutrition. World Health Organization, Nutrition for Health and Development, Sustainable development and Healthy Environments. http://www.who. int/mip2001/index.pl\%3Fiid=1735.html

RAPORT. 2002. Raport z badań monitoringowych jakości gleb, roślin, produktów rolniczych i spożywczych w 2001 roku. Collective elaboration, ed.: W. Michna and B. Szteke, Ministerstwo Rolnictwa i Rozwoju Wsi. Warszawa. 1-71.

SEIDLER T.,KASIAŻZEK J., SOBCZAKA. 2013. Determining levels of mineral consumption from foodstuff sources in the daily diets of adolescent students living in Kamień Pomorski. Roczniki Państwowego Zakładu Higieny 64, 4: 309-315.

SCHNUG E., HANEKLAUS S. 2008. Evaluation of the relative significance of sulfur and other essential mineral elements in oilseed rape, cereals, and sugar beet production. In: J. Jez (Editor), Sulfur: A missing link between soils, crops, and nutrition, CSSA-ASA-SSSA Publishing, Madison, WI. 219-233.

SIKORA J. 2007. Wybrane choroby bydła. Wydawnictwo SIMA, Warszawa. 1-176.

STANIEK H, KRÓL E, KREJPCIO Z. 2006 Ocena zawartości żelaza, cynku i miedzi w całodziennych racjach pokarmowych wybranych grup ludności. Żywność. Nauka. Technologia. Jakość 2,$47 ; 342-347$.

SULIBURSKA J. 2010. Rola składników mineralnych w rozwoju i prewencji nadciśnienia tętniczego. Forum Zaburzeń Metabolicznych 1, 4: 230-235.

TERLIKOWSKA K. M., DOBRZYCKA B., WITKOWSKA A., ZUJKO M. E. 2013. Ocena spożycia wybranych witamin i składników mineralnych wśród kobiet w wieku 40-73 lat w odniesieniu do ryzyka chorób układu sercowo-naczyniowego. Bromatologia i Chemia Toksykologiczna 46, 1: 27-23.

URIU-ADAMS J. Y., KEEN C. L. 2005. Copper, oxidative stress, and human health. Molecular Aspects of Medicine $26: 268$ 298.

USA NRC. 2000. Nutrient requirements of beef cattle: 7th Revised Edition. The National Academies Press. Washington, DC, USA. 1-234.

USA NRC. 2001. Nutrient requirements of dairy cattle: 7 th Revised Edition. National Academy Press, Washington DC, USA. 1-381.

USA NRC. 1989. Nutrient requirements of horses: 5th Revised Edition. The National Academies Press, Washington DC, USA. 1-101.

USA NRC. 1994. Nutrient requirements of poultry: 9th Revised Edition. The National Academies Press, Washington DC, USA. 1-157.

USA NRC. 1998. Nutrient requirements of swine: 10th Revised Edition. The National Academies Press, Washington DC, USA. 1- 210.

WHITE J.G., ZASOSKI R. H. 1999. Mapping soil micronutrients. Field Crops Research 60: 11-26.

Wielgos B, Teresa Leszczyńska, Aneta Kopeć, Ewa Cieślik, Ewa Piątkowska, Mirosław Pysz 2012 Ocena pokrycia zapotrzebowania na składniki mineralne przez dzieci w wieku 10-12 lat z regionu Małopolski. Roczniki Panstwowego Zakładu Higieny 63, 3: $329-337$.

WLAŹLAK E., DUNICZ-SOKOŁOWSKA A., RODOMSKA K., STETKIEWICZ T., SURKONT G., GRACZYK A. 2007. Analiza stężenia miedzi we włosach kobiet w okresie okołomenopauzalnym. Przegląd Menopauzalny 5: 303-305.

WOJCIECHOWSKA-MAZUREK E., KARŁOWSKI K., STARSKA K., BRULIŃSKA-OSTROWSKA E., KUMPULAINEN J. T. 1995. Contents of $\mathrm{Pb}, \mathrm{Cd}, \mathrm{Cu}$ and $\mathrm{Zn}$ in Polish cereal grain, flour and powdered milk. 93-101. FAO, Proceedings of the "Technical Workshop on Trace Elements, Natural Antioxidants and Contaminants", Helsinki, August 25-26.

WRÓBEL S. 2000. Wpływ wieloletniego produkcyjnego użytkowania pól uprawnych na zaopatrzenie gleb i pszenicy jarej w mikroelementy. Zeszyty Problemowe Postępów Nauk Rolniczych 471: 619-626.

ZATTA P., FRANK A. 2007. Copper deficiency and neurological disorders in man and animals. Brain Research Reviews 54: 1933.

VELU G., ORTIZ-MONASTERIO I., CAKAMK I., HAO Y., SINGH R. P. 2014. Biofortification strategies to increase grain zinc and iron concentrations in wheat. Journal of Cereal Science 59: 365-372. 